\title{
How Does Restructuring Contribute to Union Revitalization?
}

\author{
Martin Behrens \\ Wirtschafts-und-Sozialwissenschaftliches Institut \\ Richard Hurd \\ Cornell University \\ Jeremy Waddington \\ University of Manchester Institute
}

\section{INTRODUCTION}

As we look cross-nationally at labour movement revitalization, we see a complex process of change that varies depending on the socio-political/economic context. Although we observe a diverse set of union strategies and outcomes, we find that structural adjustment is a common element of revitalization efforts. The mere presence of restructuring does not, of course, assure positive results. In this chapter we define various forms of restructuring, outline factors that shape and promote restructuring, and discuss the likelihood that restructuring leads to union revitalization by using examples from our cross-country comparison.

Concrete cases of unions' structural change take a variety of forms that fall into three predominant categories. The first is 'external structure' (Clegg 1976: 40) or 'external shape' (Hyman 1975: 3), which comprises the boundaries of a labour movement. As such, external shape embraces the principles that underpin the pattern of union organization, decisions on which workers, occupations, and industries to include or exclude, as well as border or demarcation lines between unions. In some cases there are notable modifications in the relationship between different levels of the labour movement. Specifically, this might involve redefinition of the role of the peak level vis-a-vis individual national unions. External restructuring may result from altered arrangements among unions at the same level, in most notable cases leading to mergers. A union may also unilaterally engage in external restructuring by redefining its own borders. This might involve creating a subsidiary, in essence, to enter a new industry, occupation, or geographic jurisdiction in order to extend 'job territory' (Undy et al. 1981: 60).

The other two categories of union restructuring are internal to the specific organization. One internal component is union governance, the analysis of which centres on union democracy, representation, and participation (Undy et al. 1981: 37; Weil 1997: 204). It is, thus, concerned with internal union politics and relations between different groups within a union. The governance process may be altered to increase the authority exercised by a national union over its locals as part of a programme to shift priorities. The other internal category is union administration, which focuses on union management and the allocation of resources. This aspect of restructuring within a labour organization might relate to specialization of certain functions, real- location of resources, or the reform of management systems (Clark and Gray 199T. 196; Weil 1997: 217-20). While the distinctions between 
the two internal aspects of structure are not clear-cut, they capture different elements of the revitalization of union organizational life.

Whatever the form, restructuring neither automatically contributes to labour movement revitalization, nor necessarily increases a union's power. In order to appreciate the potential for meaningful restructuring and the obstacles to progress via this route, it is necessary to map both the factors that influence success and the motivations for structural change. Once a framework has been established, we will review the experience with restructuring in the five countries and will highlight those efforts with some potential to promote revitalization. At the end of the chapter we will evaluate that experience in the context of the dimensions of revitalization introduced in Chapter 2.

\section{FACTORS THAT DRIVE RESTRUCTURING}

As entrenched institutions, labour movements face major hurdles as they embrace new priorities and attempt to restructure to facilitate pursuit of these priorities. The more radical the change, the more substantial the obstacles are likely to be (Nord and Tucker 1986). As with other institutions, the most serious obstacles to union revitalization stem from internal resistance to change (Kotter 1995). Similar to other organizations, trade unions are subject to strong inertial pressures, which often allow for only a conservative transformation of their goals, structure and tactics (Selznick 1957; March and Simon 1993; Voss and Sherman 2000). There is inevitably a high degree of internal resistance faced by almost any kind of comprehensive restructuring. This may come from members comfortable with the status quo and concerned about being disenfranchised, from leaders worried about losing their political base, or from staff unsure where they will fit in the new organization (Fletcher and Hurd 2001). But what does it take to overcome this resistance? In Figure 7.1 we present a model that captures common elements of successful transformation in unions. This model is not intended as a definitive treatment of structural change, but rather as a simplification that will help highlight key aspects of the change process.

There are two mutually supportive causal chains that are associated with successful union restructuring. In the countries we have studied, resistance to restructuring is neutralized where there is a sufficient level of environmental pressure to start the process. As shown in the upper section of Figure 7.1, such pressures can raise the level of urgency within the union. Environmental pressure alone may not be sufficient, however. Awareness can be facilitated by union leaders and staff who educate members about the existence and impact of the external pressures in order to win support for organizational change (Armenakis et al. 1993; Fletcher and Hurd 2001: 207).

Environmental pressures, even when widely understood, will not directly produce comprehensive restructuring on their own, however. In addition unions need a clearly articulated conception of their future, 


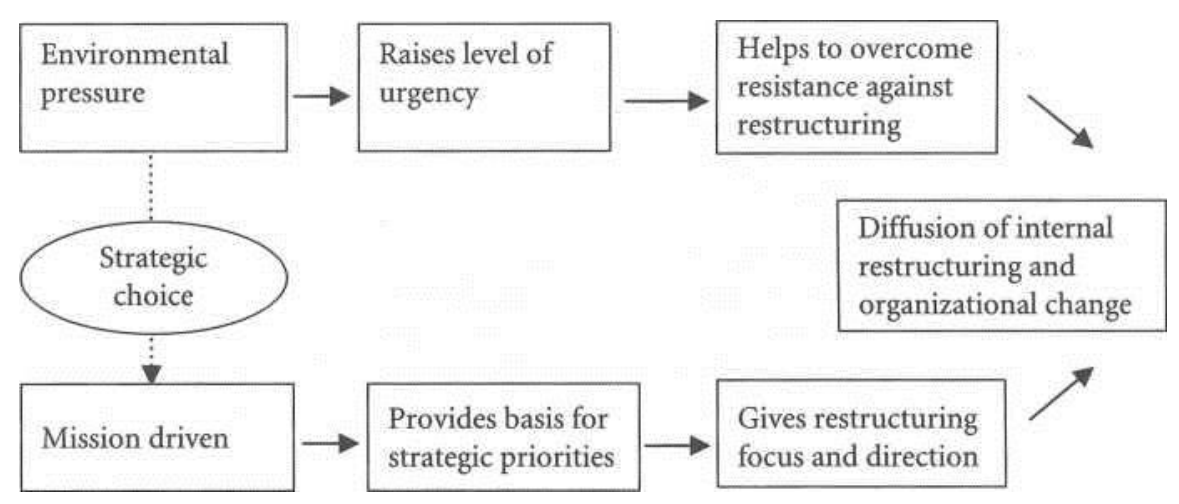

Figure 7.1. Organizational change in unions

which might be formally codified as a mission (or vision) that provides a basis for strategic priorities. This is depicted in the lower part of Figure 7.1. If restructuring is not driven by mission, or at least by clearly articulated goals, initiatives almost inevitably will stop short of transformation because there is no focus and direction (Allaire and Firsirotu 1985). This is not to say that without a mission there would not be restructuring at all, but rather that such cases would result in a limited 'structural fix' (Grabelsky and Hurd 1994; Behrens 2002).

But how are we to distinguish between structural change that is cosmetic, amounting to little more than a shortterm expedient glossing over fundamental weaknesses, and restructuring that has the potential to contribute substantially to labour movement revitalization? It is our collective qualitative judgement that the character of restructuring is linked to the motivations that initiate the change process. To help unravel the complexity of motivations for structural change, we adopt a framework that borrows heavily from the literature on union mergers.

Table 7.1 summarizes different motivations that shape the three aspects of restructuring delineated above: internal changes in union government, internal administrative modification, and external restructuring. We posit that three alternative motivations can underpin union restructuring: aggressive, defensive, and transformative. The merger literature describes cases where a larger partner seeks to assimilate other unions with the primary intent of increasing the size of the individual union (Chitayat 1979: 129; Undy et al. 1981: 167). Among the intentions that might underpin such aggressive restructuring are the consolidation and strengthening of the political control of union leaders, and the extension of the boundaries of the individual union. If restructuring is merely aggressive, however, it is unlikely to translate into net membership growth for the labour movement as a whole, nor to any notable enhancement of union bargaining power or political influence. Union leaders might implement aggressive internal restructuring to increase their personal control of a union's governance system and administrative apparatus (Chitayat 1979: 131). Alternatively, they might adopt a narrow interpretation of corporate models and attempt to increase personal power through aggressive external restructuring: for example, affiliating independent unions and adding units (Chaison 1996: 8), or possibly by reaching 'sweetheart' agreements with employers, thus adding members and dues revenue without providing representational services. 
Table 7.1. Motivation to restructure

\begin{tabular}{|c|c|c|c|}
\hline & \multicolumn{2}{|c|}{ Internal } & \multirow[t]{2}{*}{ External } \\
\hline & $\begin{array}{l}\text { Governance/ } \\
\text { Democracy }\end{array}$ & Administrative & \\
\hline Aggressive & $\begin{array}{l}\text { - Increase leader(s) } \\
\text { control of decision- } \\
\text { making } \\
\text { - Silence critics of } \\
\text { leader(s) }\end{array}$ & $\begin{array}{l}\text { - Increase } \\
\text { leader(s) } \\
\text { control over } \\
\text { budget and staff } \\
\text { - Augment } \\
\text { administrative } \\
\text { authority of } \\
\text { leader(s) }\end{array}$ & $\begin{array}{l}\text { - Growth through } \\
\text { acquisition } \\
\text { - Increase } \\
\text { external } \\
\text { influences of } \\
\text { leader(s) }\end{array}$ \\
\hline Defensive & $\begin{array}{l}\text { - Silence critics of } \\
\text { leader(s) } \\
\text { - Respond to } \\
\text { members' desires to } \\
\text { preserve status quo } \\
\text { - Insulate leader(s) } \\
\text { from external } \\
\text { shocks }\end{array}$ & $\begin{array}{l}\text { - Downsizing to } \\
\text { balance budget } \\
\text { - Resource shift } \\
\text { for survival }\end{array}$ & $\begin{array}{l}\text { - Consolidation to } \\
\text { stem decline, } \\
\text { reduce rivalry } \\
\text { - Merger/ } \\
\text { affiliation for } \\
\text { survival }\end{array}$ \\
\hline Transformative & $\begin{array}{l}\text { - Enhance members' } \\
\text { participation and } \\
\text { democracy } \\
\text { - Engage diverse } \\
\text { constituents in } \\
\text { change process }\end{array}$ & $\begin{array}{l}\text { - Align union's } \\
\text { structure with } \\
\text { mission/ } \\
\text { priorities } \\
\text { - Reallocate } \\
\text { resources to } \\
\text { promote growth }\end{array}$ & $\begin{array}{l}\text { - Capture } \\
\text { economies of } \\
\text { scale } \\
\text { - Increase union's } \\
\text { political and } \\
\text { economic power }\end{array}$ \\
\hline
\end{tabular}

In sum, if restructuring is merely aggressive, it is unlikely to translate into net membership growth for the labour movement as a whole, nor to any notable enhancement of union bargaining power or political influence.

The most commonly mentioned motivation in the merger literature is survival (Waddington and Hoffman 2000:73-4). Similarly, we label as defensive those restructuring initiatives that are reactions to declining fortunes and that attempt to stabilize the union. Although this may involve appropriate adaptation to economic change, if the restructuring is merely defensive it does not offer great potential to increase union power per se. Defensive restructuring may focus on internal procedures, attending to the short term interests of members and leaders in effect by retrenching and erecting barriers that attempt to limit the impact of external challenges and threats to the union's established culture and practice. External defensive restructuring is not as insular, however, as it involves efforts to form alliances with other organizations that might help forestall decline. The aggressive and defensive forms of restructuring capture the vast majority of union mergers. A study of union mergers in five countries by Chaison concluded that in each country, mergers were unable to resolve the fundamental problems that created them' (Chaison 1996: 165).

We turn to the organizational change literature for help in identifying restructuring with the potential to contribute to labour movement revitalization. The consistent message is that the more radical the change, the 
more essential it is to approach the effort strategically based on careful assessment and thorough preparation (Allaire and Firsirotu 1985). To capture the strategic essence of this type of change, we label as transformative those restructuring efforts tied to substantive organizational change that promise to augment union power along at least one of the four dimensions identified in Chapter 2. In other words, we argue that transformative restructuring is likely to support union revitalization.

Although such restructuring may include aggressive or defensive elements, these are pursued within the framework of the union's strategic plan. In essence the portion of Table 7.1 devoted to transformative restructuring relates back to the type of organizational change depicted in Figure 7.1. Transformative motivations are different in substance from those associated with merely aggressive or merely defensive restructuring. Internal changes of union government and union administration are pursued not to protect the vested interests of leaders and current members, but rather to engage all of the union's constituents and prospective constituents in the change process. The goal is to reform the union's governance and administrative machinery in order to address new strategic priorities. Similarly, whether it involves redefinition of the role of the confederation, mergers of individual national unions, or the creation of new union ventures, external transformative restructuring is motivated by a desire to augment the union's strategic effectiveness.

Because transformative restructuring potentially can contribute to labour movement revitalization, the next section emphasizes those transformative initiatives that are being pursued by union organizations in the five countries. We do not attempt to review all restructuring nor even to delineate all cases of structural change. Rather, we summarize the most prominent forms of restructuring and pay special attention to those with the potential to contribute to revitalization.

\section{STRUCTURAL ADJUSTMENT AND UNION REVITALIZATION}

Union restructuring can be implemented at any level of the labour movement, ranging from local unions to cross-national organizations. In order to review coherently the relevant range of structural change, it is necessary to clarify the terminology we will use. At the peak of union organization within each nation state are confederations to which national unions may affiliate. For our purposes, therefore, the American Federation of Labor-Congress of Industrial Organizations (AFL-CIO) is a confederation, although it is often referred to as a federation within the United States, as is the British Trades Union Congress (TUC) and the German Deutscher Gewerkschaftsbund (DGB). The Italian Federazione di Categoria (Industrial Federations) and the Spanish Federaciones Sindicales de Industria (Industrial Federations), the principal affiliates of the confederations in the two countries, are treated here as similar to the national unions of Britain, Germany and the United States. At the pan-European level we have cross-national organizations that are increasingly important in the context of economic integration associated with the European Union. There is the European Trade Union Confederation (ETUC) whose affiliated organizations include the European Industry Federations (EIFs), which are comprised of individual national trade unions from EU member countries. ${ }^{1}$ 
We will first look at restructuring within the five countries at the level of confederations, then look at structural change in national unions, and conclude with a review of developments at the pan-European level. Although we will highlight where possible transformative restructuring, we note in advance that much of the structural change within the five countries is defensive in character. Furthermore, even those structural initiatives with the potential to be transformative often have failed to realize this potential. This is particularly the case where membership decline and associated financial weakness, have prompted unions to react more defensively. Nonetheless, there are clear examples with the potential to aid labour movement revitalization in each of the five countries. Furthermore, the institutional change that has accompanied the European Union since 1990 has created an environment more conducive to substantive innovation. In consequence, pan-European trade union institutions exhibit a marked structural vitality.

\section{Peak Level: Confederations}

The trajectory of recent developments in our five countries is affected by differences in the function and structure of confederations and by the influence they exercise over affiliated unions. In particular, Italian and Spanish confederations have a more wide-ranging bargaining function than their American, British, and German counterparts. To facilitate the undertaking of this wider bargaining function, Italian and Spanish confederations have greater authority over affiliated unions. By comparison American, British, and German national unions vigorously protect their autonomy from confederal interference. Furthermore, in Italy and Spain several confederations compete on the basis of different political allegiances, ${ }^{2}$ whereas elsewhere confederal structure is unitary. ${ }^{3}$ Italian and Spanish confederations collect union income and disperse it to affiliated organizations, whereas the reverse is the case in Britain, Germany, and the United States. This distinction further compounds the differences in the relationships between confederations and affiliated organizations.

Irrespective of these differences, a consistent theme among the confederations of the five countries is the extension and reform of external shape. To expand the external boundaries in Britain, Germany, and the United States, confederations have encouraged new affiliations, particularly of unions that organize in the expanding sectors of the economy. Since 1995 the TUC has accepted fourteen additional unions into affiliation, ${ }^{4}$ while both the United American Nurses and the California School Employees recently affiliated to the AFL-CIO. Similarly, the DGB encouraged the involvement of the Deutsche Angestellten Gewerkschaft (DAG) in the Vereinte Dienstleistungsgewerkschaft (ver.di) merger in 2001, thereby bringing the DAG within the scope of the DGB for the first time since 1945. In Italy and Spain the relative strength of the confederations allows them to have greater influence on the pattern of expansion. Since 1998, for example, the three major Italian confederations have each established unions specifically to organize and represent 'parasubordinates' or labour only sub-contractors (Fullin 2002; Baccaro, Carrieri, and Damiano 2003: 45).

The promotion of mergers is at the core of policy initiatives to reform external shape. Again, however, differences in the political position of the confederations influence the character of these initiatives. The AFF-CIO, DGB, and 
TUC have no direct authority over the merger process. In consequence, while the merger process has reduced the number of affiliated unions, these confederations have had little influence over which unions are involved in specific mergers. For example, between 1990 and 2001 each experienced a decline in the number of affiliates largely as a result of mergers: AFF-CIO, from eighty-nine to sixty-six; DGB, from seventeen to eight; and TUC, from seventy-six to seventy-three. ${ }^{5}$ Because of the limited role of the confederation, there is no consistent principle of organization that influences merger choices, with the consequence that the merger process has not simplified' trade union structure. In contrast, in Italy and Spain the confederations have been able to guide mergers between affiliated organizations. In Spain, this influence has been brought to bear to promote sectoral organization at the expense of regional structures (Hamann and Martinez Fucio 2003).

One issue concerning external shape specific to Italy and Spain is the closer working or merging of confederations. Throughout the 1970s and until the mid-1980s the Italian confederations maintained a formal alliance administered through the Federazione Unitaria with representation from the three confederations. During this period the prospect of a confederal merger was raised, although the different political affiliations of the confederations constituted an insurmountable barrier (Kreile 1988; Focke and Baccaro 1996). The dissolution of many of the traditional party- confederation affiliations following Tangentopoli (corruption scandals) in 1992 facilitated the development of the unity of action between the confederations and a formal proposal to merge in 2000. Political differences re-emerged after 1998, however, once again putting the merger proposal on hold. Similarly, in Spain the unidad de accion (unity of action) between Union General de Trabajadores (UGT) and Comisiones Obreras (CC.OO.) until 2001 represented a weakening of traditional political animosities. While the emergence of confederal mergers on the union agenda in Italy and Spain represents a marked shift in attitudes, with the occasional breakdown of these alliances in both countries it is clear that considerable barriers have yet to be overcome before they are realized and external shape is transformed.

Most of the confederations in the five countries have introduced limited changes to systems of government. In particular, systems of reserved seats for women, white-collar, young, and ethnic minority workers are now commonplace (Braithwaite and Bryne n.d.; Garcia, Hacourt, and Lega n.d.). For the most part, representation within confederations remains dependent upon the membership size of the affiliated union, a system that has been in place for much of the twentieth century. It is only in Italy that transformative changes to systems of union government have been introduced, although even these changes had their origin in defensive counter-measures.

Three developments promoted the shift in the systems of Italian confederal government. First, after the mid1970s many skilled workers left unions affiliated with the confederations after the reforms to the scala mobile, which narrowed wage differentials based on skill (Regini and Regalia 2000). Second, a large number of sindicati autonomi (autonomous unions) were established to represent the interest of white-collar workers, who regarded the confederations as focusing too strongly on the interests of manual workers. Third, Comitati di Base (COBAS, rank-and-file committees) were established, primarily in the public and service sectors, in opposition to the policies and practices of the three confederations. In combination, these developments constituted a crisis for- 
confederal union organization in Italy (Kreile 1988; Bordogna 1989). In response, the confederations instigated a series of reforms including the practice of submitting all major collective agreements to a binding vote of the membership. Coupled with legal reforms on plant-level representation structures (rappresentanze sindicati unitarie), this reform 're-legitimized' confederal organization and was associated with increases in membership, particularly in the service sector (Ponzellini and Provenzano 2001).

The range of administrative reforms undertaken by confederations in the five countries follows similar trajectories. Increased use of the web and sophisticated electronic hardware and software is widespread (Greene, Hogan, and Grieco 2003: Kahmann 2003; Martinez Lucio 2003), as are efforts to improve the quality of service offered by confederations. The latter point is of particular significance in Italy and Spain as it represents a formal acknowledgement that members must be engaged in union activity and politics. More specifically, the TUC has jettisoned much of its formal standing committee structure and introduced a series of task groups, which are dedicated to particular campaigns and are dissolved when the campaign objectives have been achieved. Consistent with this accentuation of the TUC's role in campaigning, a Communications Department was established to publicize campaigns initiated by the TUC (Heery 1998). In this context the TUC has successfully launched high-profile campaigns on organizing and partnership and has been able to cascade the objectives of these campaigns down to affiliated unions. The founding of the Organizing Academy to recruit and train organizers was a particularly important step.

Similarly, the election of John Sweeney to the presidency of the AFL-CIO in 1995 led to wide-ranging internal reorganization of staff, departments, and field operations. Especially important was the creation of an organizing department and major expansion of the Organizing Institute. Efforts to encourage the adoption of organizing as a priority have also intensified. More recently, the AFL-CIO has downgraded the position of the 'unwieldy' fiftyfour-member Executive Council and established a seventeen- member Executive Committee in order to streamline confederal policy-making and to sharpen the focus of the AFL-CIO on political and organizing objectives (Greenhouse 2003). There is no doubt that these and similar initiatives have contributed to an impression of institutional vitality and may have enhanced administrative efficiency.

However, resistance to confederal initiatives remains entrenched in both Britain and the United States. Furthermore, union density in the two countries continues to decline. Efforts to lead revitalization from the centre, thus, remain problematic in the absence of direct confederal authority over affiliated unions. In Spain, where confederal authority is more wide-ranging, campaigning teams have been deployed by the confederations to raise membership levels, particularly during works council elections (Hamann and Martinez Lucio 2003). It remains in question whether such an approach leads to long-term membership gains. When coupled to the professionalization of service delivery, this approach may also be associated with increased centralization and the lowering of members' engagement in union activity (Sverke and Sjoberg 1997; Hamann and Martinez Lucio 2003). At the level of confederations, then, we have two promising types of structural change. In Italy and Spain where 
confederations maintain closer control over their affiliates, confederal restructuring has the capacity to drive revitalization. Reductions in inter-confederal rivalries have transformative potential particularly in the political arena where labour has become a more credible force as a result of heightened unity (see Hamann and Kelly, Chapter 6, this volume). In the United Kingdom and the United States, with more decentralized traditions, the TUC and AFL-CIO have used structural change to increase the influence of the centre. The creation of the Organizing Academy, expansion of the Organizing Institute and the shift of resources to support organizing have helped the two confederations become pattern-setters. They are actively spreading knowledge, practical skills, and vision throughout the labour movement. This restructuring has clear transformative potential in countries with declining union density.

\section{Revitalization and National Union Structure}

In each of the five countries under discussion, mergers and other forms of closer coordination are commonplace as a means to reform external shape among national unions. The driving force for most mergers, though, is membership decline and associated financial weakness (Chaison 1986; Waddington, Kahmann, and Hoffmann 2003). The contraction of employment in specific industries is particularly effective in promoting mergers when it occurs in the context of industrial unionism. Trade unions in the agriculture, mining, textile, and timber industries, for example, have been acquired by larger unions in many countries with the result that independent union organization in these industries no longer exists. Furthermore, potential economies of scale are too often dissipated in post-merger rationalization and early retirement schemes, which are often introduced to reduce the number of full-time staff in the combined organization. Thus, most mergers fit the category of defensive restructuring.

Some mergers completed by larger unions, however, have the stated intent of extending organization to sectors of the economy where the parent union had no initial presence. To be successful such policies require both strategic selection of merger partners and considerable post-merger investment in recruitment and organizing. The Service Employees International Union's (SEIU) merger with 1199 (National Health and Human Service Employees) in 1998 enabled the acquiring union to increase membership in the health sector by 25 per cent to 500,000 (Fan 1998: 26). This augmented earlier mergers and clearly established SEIU as the dominant health care union in the United States, a position that was subsequently solidified by shifting substantial resources to organizing to secure a more wide-ranging presence. Similarly, the large newly established German service sector union, ver.di, resulted from a merger of five unions and displaced IG Metall as the largest union in Germany.

In Britain, Germany, and the United States, confederations exert no direct influence on national union structure. Decisions on mergers and other steps to alter external shape rest almost exclusively within the national unions involved. In consequence, the external shape of the union movements in these countries exhibits no uniform pattern of development. In Britain and the United States, larger unions are tending to extend their membership bases both by mergers and through recruitment efforts. Although traditional jurisdictions sometimes influence 
national union decisions regarding external boundaries, there is a consistent trend for memberships to become more heterogeneous. With the new membership base extending both vertically and horizontally, an increasing number of organizations are adopting the characteristics of general unions, with only limited industrial and occupational restrictions to recruitment. Although there are exceptions, in Germany, Italy, and Spain multiindustry unions tend to result from mergers as industrial unions combine. In Germany, for example, Industriegewerkschaft Metall (Metal Workers' Union) acquired the Gewerkschaft Textil-Bekliedung (Textile and Clothing Union) and the Gewerkschaft Holz und Kuntstoft (Wood and Plastics Union) to extend its recruitment base beyond its traditional base in engineering.

Increasing membership heterogeneity is also associated with new forms of union government. Similar to confederal restructuring, many unions have supplemented regional and industrial forms of representation with structures for women, white- collar, young, and ethnic minority workers. Such measures reflect changes in membership composition and are intended to raise participation levels among such groups, to encourage horizontal interlinkages between different vertically organized groups of members, and to facilitate the development of union policies to incorporate items of direct concern to these groups. In short, as membership becomes more heterogeneous, systems of union government become more sophisticated. Arguably, union government also becomes more expensive in such circumstances, thus mitigating the impact of any economies of scale that might arise from merger involvement (Waddington, Kahmann, and Hoffmann 2003).

It is also far from clear-cut that these measures have achieved their intended results. Take the case of women, for example. A variety of reserved seats systems, women's sections and the appointment of Women's Officers, have raised the profile of women trade unionists, although they tend to operate only at the senior levels within the union hierarchy rather than at local or regional levels. These systems have yet to result in the proportional representation of women in the decision-making structure of most unions at the national level (Braithwaite and Byrne n.d.; Garcia et al. n.d.), although women s sections have allowed more women to participate in union affairs. Furthermore, they have acted as additional articulating mechanisms that assist in linking the local and regional levels with national activities. They have, not however, elevated the status of issues of specific concern to women during bargaining (Cyba and Papouschek 1996; Colling and Dickens 1998). Nor have they prevented large numbers of women from leaving unions and citing the inadequacy of union organization as being their prime reason (Waddington and Kerr 1999). Many of these new approaches to union government have, thus, not yet transformed systems of union democracy.

Two developments have greater potential for change: the systems of union government adopted by UNISON in Britain and ver.di in Germany. Both of these unions were founded by merger, and representatives of the participating unions set out to establish 'new' unions. ${ }^{6}$ Underpinning the approach adopted by UNISON and ver.di is the principle of proportionality, whereby the composition of each committee within the union must reflect the composition of the membership. In other words, if 60 per cent of a group of members are women, then 60 per cent of the committee that represents the group should also be women. Allied to the adoption of the principle of 
proportionality in UNISON are novel approaches to fair representation and self-organization. The UNISON rulebook defines fair representation as,

The broad balance and representation of members of the electorate, taking into account such factors as the balance between part-time and full-time workers, manual and non-manual workers, different occupations, skills, qualifications, responsibilities, race, sexuality and disability. (UNISON 1993: 65)

Self-organization is also promoted among women members, black members, members with disabilities, and gay and lesbian members. In combination, these approaches by UNISON have reshaped the traditional model of trade union democracy (McBride 2001). Women, black and gay and lesbian members are engaged in decision-making processes on a wider scale than hitherto and have developed new skills appropriate to this engagement (Humphrey 2002). Furthermore, alliances between different self- organized groups are now likely and present opportunities to extend the influence already secured (Colgan and Ledwith 2000). While the situation in ver.di is less developed because the merger was more recent, the point is that these approaches constitute a significant development beyond traditional approaches to equality.

There have also been marked shifts in the approaches of national unions to administration, with an increased emphasis placed on efficiency, new management techniques, and budgetary control. German and Spanish unions have paid particular attention to the provision of increasingly sophisticated legal services, reflecting the juridified industrial relations systems of the two countries (Schmidt and Trinczek 1993; Hamann and Martinez Lucio 2003). In addition, several German unions such as the construction workers union IG BAU, the IG Metall, and the chemical and mineworkers unions IG BCE have initiated comprehensive programmes for organizational development which seek to optimize the division of labour within the union to formalize routines, and to distribute efficiently both responsibilities and resources. In several cases, these programmes involved outside consultants (Behrens, Fichter, and Frege 2001: 15-16).

Increased use of opinion polls and market research to obtain the views of members and non-members, coupled to the targeting of specific groups of potential members, is now more widespread. In Germany, for example, the IG Metall initiated a so-called 'debate on the future' (Zukunftsdebatte) which included polling weeks' used to determine the views of the 120,000 workers who took part in surveys, interviews, and group discussions. In addition, the union commissioned nine comprehensive literature reviews on subjects related to the debate (EIRO 2002). In some instances devolved budgetary control has been introduced in conjunction with the centralized setting of targets and monitoring of individual performance, which has facilitated the retention of centralized control within an overall tendency of shifting more resources to the local level (Waddington, Kahmann, and Hoffmann 2003). This tendency is most marked where bargaining is decentralized.

There are very few examples where the introduction of administrative change has transformed union organization. Even where organizing budgets have been markedly increased, the absence of a clear connection between a union's membership strategy and broader transformative restructuring has often undermined the impact of the additional funds. Two notable exceptions in the United States to this general framework are the 
SEIU and the United Brotherhood of Carpenters (UBC). The SEIU now allocates 50 per cent of its national budget to organizing and requires locals to follow suit wherever possible. These initiatives, however, are also connected to partial revisions of union government. To move the process along, the SEIU is engineering mergers of locals it deems too small to pursue an effective organizing agenda independently. Although this intrusion into local union affairs has been questioned in some quarters within the union, support among elected leaders for the organizing priority has helped control opposition. Top-down structural change has been matched by an aggressive grassroots organizing approach, as the SEIU has continued its steady growth while other unions have struggled (Hurd, Milkman, and Turner 2003: 102, 111). The change effort is mission-driven under the union's New Strength and Unity Programme and clearly has transformative potential.

The UBC's top-down restructuring has been successful in the particular sense of recruiting additional members, but has stirred controversy. Shortly after assuming the union's presidency in 1995, Doug McCarron cut national office staff by half, eliminated departments, and rented out nine and one-half floors of the ten storey national headquarters to generate revenues. These changes helped fund a shift of 50 per cent of the union's resources into organizing. Subsequently, McCarron reorganized the union's regional and local structure, eliminating many locals and shifting control of resources to regional councils dominated by his political allies (Cleeland 2002). These aggressive changes have allowed the UBC to expand its organizing programme dramatically. Membership increased from about 500,000 in 1996 to 538,000 in 2002 (Gifford 1997: 50, 2003: 42). Although there are transformative elements to the UBC restructuring in terms of labour movement revitalization, there have been destructive components as well. On 29 March 2001 the UBC seceded from the AFL-CIO, ostensibly because the Sweeney administration compromised its commitment to organizing (Cleeland 2002).

The most promising restructuring at the national union level is tied to internal modifications. Although formed by mergers, the transformative aspects of the operation of UNISON in the United Kingdom and ver.di in Germany are the governance systems created by the new organizations with provisions to increase the role of women, minorities and young union members. In the United States, both the SEIU and UBC have restructured administration and governance to elevate dramatically the importance of organizing initiatives.

\section{Pan-European Level}

The development of the ETUC and the EIFs is closely linked to the successive enlargements of the European Union and to the process of European integration. From the perspective of external shape, both the ETUC and the EIFs have thus repeatedly extended their coverage to embrace successive enlargements. This happened with the affiliation of the communist-oriented confederations, and most recently the accession of confederations from Central and Eastern Europe. With the affiliation of the Confederation Generale du Travail (CGT) in 1999, the coverage of the ETUC was almost complete in Western Europe. Only some small confederations of civil servants and professional and managerial workers are now outside. Over 60 million trade union members from more than thirty countries are affiliated to the ETUC through confederations and national unions. 
While this pattern of development has markedly extended the external shape of the ETUC, it has merely allowed the coverage of the ETUC to match that of the European Union. In other words, to retain influence in the European Union the ETUC was obliged to extend coverage. Internal democracy remains embedded in an 'intergovernmental' system based on nationality and membership size. Recent reviews of this system, under the chair of Johan Stecklenburg (1990) and John Monks respectively, have not recommended fundamental changes to the operation of this system. The 4-yearly congress ${ }^{7}$ remains the supreme decision-making body, while an Executive and a relatively small secretariat are responsible for administering the organization between congresses.

Concurrent with the Stecklenburg review was a series of important developments within the European Union. The most prominent among these were preparations for the single market, an Intergovernmental Conference on treaty reform, negotiations on a framework to institutionalize the role of the social partners, and preparations for economic and monetary union. In combination these developments prompted two structural reforms of the ETUC of transformative potential.

The first of these concerned the assignment of wider bargaining powers to the ETUC by affiliated confederations at the ETUC Congress in, 1991. The extent of the bargaining powers granted to the ETUC were not as wide-ranging as initially envisaged by those that proposed the motion, due largely to opposition from Nordic confederations (Dolvik 1999: 132-40). The granting of any authority to the ETUC to enable it to bargain independently, however, represented a fundamental transformation to its political influence. The subsequent engagement of the ETUC in negotiations on a range of issues including European works councils, parental leave, part-time workers, and fixedterm contracts of employment, together with its involvement in broader matters of social dialogue, illustrate the impact of the initial decision to grant it bargaining rights. Although the direction of ETUC policy is contested (Waddington 2000), movement towards a European industrial relations area required an ETUC with the authority to bargain, a development of transformative potential.

A second reform of the ETUC adopted in 1991 arose from a recommendation of the Stecklenburg Report. The constitution of the ETUC initially allowed only national level confederations to affiliate directly. In 1991 this was amended to enable EIFs to affiliate directly to the ETUC, and to grant seats to representatives of the EIFs on the Executive of the ETUC. In practice, this decision meant that national unions were linked to the ETUC through two routes; geographically via a national confederation and sectorally via the EIFs. The adoption of this measure, thus, represented the abandonment of country of origin as the sole basis to organization.

The amendment also has the long-term potential to be transformative in the context of bargaining power. Throughout Europe a range of cross-border bargaining initiatives were developed after about 1995, most of which were sector-specific and fostered by unions affiliated to particular EIFs (Gollbach and Schulten 2000; Prince 1995). Furthermore, in 1999 the ETUC Congress resolved to strive for 'the paramount goal' of a coordinated collective bargaining policy 'developed at sectoral or cross- sectoral level' with 'primary responsibility for coordination in the field of collective bargaining at European level' allocated to the EIFs (ETUC 1999: 67). There are many 
difficulties to overcome before European sectoral bargaining becomes a reality, not the least of which is the absence of employers' organizations prepared to enter into bargaining arrangements. Designating the principal role in this function to the EIFs, however, represents the potential to diminish further the influence of the national confederations and to transform the ETUC into a European confederation of EIFs, each of which conducts bargaining.

The institutional vitality of trade union organizations at the pan-European level is thus associated with the developing polity of the European Union. The development of a bargaining function by the ETUC and marked shifts in the position of the EIFs represent changes of transformative potential. Other reforms of the EIFs are more defensive in character. The reduction in the number of EIFs after 1996 as a result of mergers, for example, results primarily from membership decline and financial weaknesses. ${ }^{8}$ Furthermore, there is little or no correspondence between these mergers and the structural reform of national unions, thus minimizing any benefits that might arise from economies of scale. The limited resources available to the EIFs also limit the transformative capacity of all of these developments. National level union organizations are the primary source of these resources. Membership decline, and associated financial difficulties at the national level effectively restricts the allocation of additional resources to the pan-European level.

In sum, restructuring at the pan-European level has great transformative potential. The wider role established by the ETUC within the European Union has substantially increased labour's political influence. Furthermore, the direct affiliation of the EIFs with the ETUC has opened the window of opportunity for European level bargaining and wider sectoral integration.

\section{THE CONTRIBUTION OF STRUCTURAL CHANGE TO UNION REVITALIZATION}

Restructuring has been integral to revitalization initiatives in all five of the countries we have studied and at the pan-European level. National unions have pursued mergers and introduced internal reforms in governance and administration with the clear intent to achieve transformative results. Confederations have restructured to demonstrate new priorities and to lead renewal efforts. The ETUC working with EIFs has been actively involved in shaping labour's role in the emerging integration of the European economy. Our review shows that there are indeed incidents of structural change that meet the standard of 'transformative' restructuring, or at least have transformative potential. During a time of upheaval in labour relations systems, only transformative restructuring with its embedded strategic perspective can contribute to labour movement revitalization. Because union external shapes were established when different social, political, and economic circumstances prevailed, it is necessary to reform trade union structures to eliminate outdated demarcations. Furthermore, internal reform of systems of union government and administration provides the opportunity to by-pass conservative vested interests and introduce new systems appropriate for the changed environment. While possibly an insufficient basis for union revitalization in its own right, transformative restructuring will almost certainly play a key role in 
labour movement renewal. But have the restructuring efforts as described been successful? Has the transformative intent translated into actual revitalization? In order to interpret further the impact of restructuring it is useful to return to the four dimensions of labour movement revitalization introduced in Chapter 2.

Within the membership dimension restructuring at both the confederation and national union levels has the capacity to shift resources to organizing, and also to achieve economies of scale which may free resources for intensified recruitment campaigns. Thus, mergers are frequently justified to enlarge membership numbers and to overcome competition in organizing members between unions with overlapping jurisdictions. However, although strategically driven mergers and targeted creation of subsidiaries may facilitate national union organization in new arenas, or may intensify organizing in markets where the union is already established, this type of result seldom accompanies the widespread effort to consolidate unions in the countries we have studied (see Heery and Adler, Chapter 4, this volume). In addition, restructuring can be used to enhance organizing strategies. The TUC and the AFL-ClO have taken the lead in establishing organizing as a priority in the United Kingdom and the United States, shifting resources and creating new units to achieve this result. Individual unions in the United States, especially SEIU and UBC have gone even further by reorienting the respective unions to recruitment activity.

Restructuring also can affect the economic dimension of revitalization, in three ways. First, by improving administration, unions gain resources and organizational flexibility. Second, restructuring may enable unions to establish more effective ways to process information on the outcomes of bargaining and other union activities, and use the information to mobilize members and resources more effectively. Third, by changing external structure unions can reform the bargaining framework and level to 'fit' changing labour markets and company organizational structure. Unfortunately, the evidence we have reviewed does not indicate great progress along the economic dimension. Increased coordination among confederations in Spain and Italy has, however, contributed at least modestly to increased leverage. Perhaps the greatest potential exists at the pan-European level where the EIFs offer the opportunity to deal more effectively with multinational corporations.

Structural change can have an effect on the political dimension of revitalization in two respects. First, by changing their external structure unions can pool their resources vis-ä-vis political power holders and gain leverage in the field of political lobbying or corporatist arrangements. In this regard, increased collaboration in Italy and Spain has improved the political influence of confederations. Similarly, increased support for the ETUC that accompanied direct affiliation by the EIFs enhanced political influence within the European Union. Second, improvements in the field of union government provide labour's political allies with an opportunity to benefit from their legitimacy. In spite of some evidence of positive change in this aspect of internal operation, there is little evidence of associated increase in political influence.

The potential power of structural change is strongest in the institutional dimension, which was defined as a composite of unions' institutional shape, identities and dynamics. Although structural change clearly alters the shape of union institutions, this alone is not sufficient to assure progress towards revitalization. In contrast to the 
old institutionalists', many of whom were inspired by Robert Michels and the iron law of oligarchy (1989), the potential power of restructuring is viewed here as infusing a commitment to dynamic change into the union. In other words, if structural change helps labour overcome strategic rigidity and accept innovation, then there is clearly progress in this dimension. The restructuring that has occurred in the United States and the United Kingdom to promote organizing, or in some German unions to promote more democratic and efficient organizations, has certainly contributed to institutional vitality. Similarly, the confederal reforms in Italy and Spain have strengthened coordination and injected new life into those labour movements. Also, the increased visibility and role of the ETUC has helped to infuse dynamic change into that organization.

In spite of these encouraging signs at various levels of the labour movements in and across these countries, we must conclude that structural change in itself does not hold great potential to drive revitalization. Restructuring, clearly, has enhanced institutional vitality at all levels in a variety of ways. However, this is not enough. Without more substantial progress in the membership, economic, and political dimensions, this institutional progress will have little substantive impact. Moreover, it is only in conjunction with other strategic approaches that restructuring becomes important. In fact, it is in the context of new organizing, political and bargaining strategies, and the emergence of new international initiatives that structural change takes on the crucial role of institutionalizing labour movement revitalization.

\section{Notes}

1. In practice, European Industry Federations may be independent organizations, that attract members from within the European Union and a broader Europe, or they may be regional organizations of International Trade Secretariats. As this distinction does not have significance in the context of union revitalization, its implications are not examined in detail here.

2. In Spain, there are also confederations based on specific regions. These confederations are excluded from this analysis.

3. We classify Germany as a unitary system, although it should be noted that there are some small pockets of inter-union rivalry where the DGB's affiliates are facing competition from independent unions or union federations. The Christian Trade Union Federation of Germany (Christlicher Gewerkschaftsbund, CGB), as the most important of those competing federations, represents about 300,000 employees in several industries. In addition, some rival unions such as the pilots' union Cockpit or the Independent Association of Flight Attendants (Unabhängige Flugbegleiter Organization, UFO) were created in opposition to the DGB and its affiliates.

4. Affiliations to the TUC since 1995 include Professional Footballers' Association, Community and Youth Workers' Association, Community and District Nursing Association, UNIFI, Independent Union of Halifax Staff, Society of Chiropodists and Podiatrists, British Dietetic Association, Association of Flight Attendants-Heathrow Local, Association of Teachers and Lecturers, Alliance and Leicester Group Union of Staff, Association of Educational Psychologists, Nationwide Group Staff Union, Woolwich Independent Staff Union, and the Britannic Field Staff 
Association.

5. As noted above the TUC was also active in attracting new affiliates in the same period. The extent of the decline among the population of affiliated unions of 1990 is thus understated by these figures.

6. UNISON was formed in 1993 by the merger of the Confederation of Health Service Employees, National and Local Government Officers' Association, and the National Union of Public Employees. Ver.di was formed by merger in 2001 from Deutsche Angestellten Gewerkschaft, Deutsche Postgewerkschaft, Gewerkschaft Handel, Banken und Versicherungen, Industriegewerkschaft Medien and Gewerkschaft Öffentliche Dienste, Transport und Verkehr. Both unions organize service workers: UNISON in just the public services, whereas ver.di organizes across all services. Furthermore, the two unions are the largest unions in their respective countries (for details, see Waddington et al. 2003).

7. Before 1991 the ETUC congress was held every third year and every fourth year thereafter.

8. Several mergers involving ElFs took place from the mid-1990s. Among these mergers were the formation of the European Mine, Chemical and Energy Workers' Federation from the European Federation of Chemical Workers' Unions and the Miners' European Federation, and the acquisition of the European Federation of Agricultural Workers' Unions by the European Committee of Food, Catering, and Allied Workers' Unions. In addition, the international trade secretariats of the International Federation of Commercial, Clerical, Professional, and Technical Employees, Communications International and the International Graphical, Media and Entertainment Federation merged to form Union Network International (UNI). This merger was also carried through at European level where the respective European regional organization merged to form UNI-Europa.

\section{References}

Allaire, Y. and Firsirotu, M. (1985). 'How to Implement Radical Strategies in Large Organizations'. Sloan Management Review, Spring, 26: 19-33.

Armenakis, A., Harris, S., and Mossholder, K. (1993). 'Creating Readiness for Organizational Change'. Human Relations, 46/6: 681-701.

Baccaro, L., Carrieri, M., and Damiano, C. (2003). 'The Resurgence of Italian Confederal Unions: Will It Last?'. European Journal of Industrial Relations, 9/1: 43-60.

Behrens, M. (2002). Learning from the Enemy? Internal Union Restructuring and the Imitation of Management Strategies. Ithaca, NY: Cornell University Ph.D. Dissertation.

---- Fichter, M., and Frege, C. (2001). Unions in Germany: Searching to Regain the Initiative.

Düsseldorf: WSI-Diskussionspapier Nr. 97.

Bordogna, L. (1989). 'The COBAS Fragmentation of Trade Union Representation and Conflict'. Italian Politics, 3: 50-64.

Braithwaite, M. and Byrne, C. (n.d.). Women in Decision-making in Trade Unions. Brussels: European Trade Union Confederation.

Chaison, G. (1986). When Unions Merge. Lexington, MA: Lexington Books.

---- (1996). Union Mergers in Hard Times. Ithaca, NY: Cornell University Press. 
Chitayat, G. (1979). Trade Union Mergers and Labor Conglomerates. New York: Praeger Publishers.

Clark, P. and Gray, L. (1991). 'Union Administration', in G. Strauss, D. Gallagher, and J. Fiorito, (eds.), The State of the Unions. Madison, WL- Industrial Relations Research Association, 175-200.

Cleeland, N. (2002). ‘Organize or Die'. Los Angeles Times Magazine, 10 March.

Clegg, H. (1976). Trade Unionism under Collective Bargaining. Oxford: Blackwell.

Colgan, F. and Ledwith, S. (2000). 'Diversity, Identities and Strategies of Women Trade Union Activists'. Gender, Work and Organization, 7/4: 242-57.

Colling, T. and Dickens, L. (1998). 'Selling the Case for Gender Equality: Deregulation and Equality Bargaining'. British Journal of Industrial Relations, 36/3: 389-412.

Cyba, E. and Papouschek, U. (1996). 'Women's Interests in the Workplace: Between Delegation and Selfrepresentation'. Transfer, 111: 61-81.

Dolvik, J.-E. (1999). An Emerging Island?. Brussels: European Trade Union Institute.

ETUC. (1999). Resolutions from 9th Congress. Brussels: European Trade Union Confederation.

EIRO. (2002). IG Metall Debates Manifesto For The Future, www.eiro.eurofound.ie/2002/06/ Feature/DE0206205F.html.

Fan, M. (1998). 'Unions Join in Powerful Alliance'. New York Daily News, 8 January.

Fletcher Jr., B. and Hurd, R. (2001). 'Overcoming Obstacles to Transformation: Challenges on the Way of New Unionism', in L. Turner, H. C. Katz, and R. W. Hurd (eds.), Rekindling the

Movement: Labor's Quest for Relevance in the Twenty-First Century. Ithaca NY: ILR Press, 182-208.

Fullin, G. (2002). 'The Unions for Atypical Workers in Italy'. Transfer, 8/3: 531-5.

Garcia, A., Hacourt, B., and Lega, H. (n.d.). The Second Sex of European Trade Unionism. Brussels: European Trade Union Confederation.

Gifford, C. (1997). Directory of U.S. Labor Organizations: 1997 edition. Washington, DC: Bureau of National Affairs. -----(2003). Directory of U.S. Labor Organizations: 2003 edition. Washington, DC: Bureau of

National Affairs.

Gollbach, J. and Schulten, T. (2000). 'Cross-Border Collective Bargaining Networks in Europe'. European Journal of Industrial Relations, 6/2: 161-79.

Grabelsky, J. and Hurd, R. (1994). 'Reinventing an Organizing Union: Strategies for Change', in Proceedings of the Forty Sixth Annual Meeting, (Boston, January 3-5), pp. 95-104. Madison, WI: Industrial Relations Research Association.

Greene, A.-M., Hogan, J., and Grieco, M. (2003). 'E-Collectivism and Distributed Discourse: New Opportunities for Trade Union Democracy'. Industrial Relations Journal, 34/4: 282-9.

Greenhouse, S. (2003). 'Worried about Labor's Waning Strength, Union Presidents form Advisory Committee'. New York Times, 9: 22 March.

Hamann, K. and Martinez Lucio, M. (2003). 'Strategies of Union Revitalization in Spain: Negotiating Change and Fragmentation'. European Journal of Industrial Relations, 9/1: 61-78.

Heery, E. (1998). 'The Relaunch of the Trades Union Congress', British Journal of Industrial Relations, 36/3: 33960 .

Humphrey, J. (2002). Towards a Politics of the Rainbow: Self-organization in the Trade Union Movement. Aldershot: Ashgate.

Hurd, R., Milkman, R., and Turner, L. (2003). 'Reviving the American Labor Movement'. European Journal of Industrial Relations, 9/1: 99-117. 
Hyman, R. (1975). Industrial Relations: A Marxist Introduction. Basingstoke: Macmillan.

Kahmann, M. (2003). Trade Unions and the Growth of the Information Economy. Brussels: European Trade Union Institute, Discussion and Working Paper.

Kotter, J. (1995). 'Leading Change: Why Transformative Efforts Fail'. Harvard Business Review, 73/2: 59-67.

Kreile, M. (1988). 'The Crisis of Italian Trade Unionism in the 1980s'. West European Politics, 11/1: 54-67.

Locke, R. and Baccaro, L. (1996). 'Learning from Past Mistakes? Recent Reforms in Italian Industrial Relations'. Industrial Relations Journal, 27/ 4: 289-303.

March, J. and Simon, H. (1993, first published 1958). Organizations, 2nd edn. Oxford: Blackwell.

Martinez Lucio, M. (2003). 'New Communications Systems and Trade Union Politics: A Case Study of Spanish Trade Unions and the Role of the Internet'. Industrial Relations Journal, 34/4: 334-47.

McBride, A. (2001). Gender Democracy in Trade Unions. Aldershot: Ashgate.

Michels, R. (1989, first published 1910). Zur Soziologie des Parteiwesens in der modernen Demokratie, Untersuchungen über die oligarchischen Tendenzen des Gruppenlebens. Stuttgart: Alfred Kroner Verlag.

Nord, W. and Tucker, S. (1986). Implementing Radical and Routine Innovation. Lexington, MA: Lexington Books.

Ponzellini, A. and Provenzano, E. (2001). 'Italy: The Services Sector-Towards a More Inclusive and Flexible Labour Market', in J.-E. Dolvik (ed.), At Your Service. Brussels: Peter Lang, 305-40.

Prince, J.-P. (1995). Interregional Trade Union Councils in Europe. Brussels: European Trade Union Institute, DWP 95.03.01.

Regini, M. and Regalia, I. (2000). 'The Prospects for Italian Trade Unions in a Phase of Concertation, in J. Waddington and R. Hoffmann (eds.), Trade Unions in Europe: Facing Challenges and Searching for Solutions. Brussels: European Trade Union Institute, 365-92.

Schmidt, R. and Trinczek, R. (1993). 'Fusion und Konfusion: Gründe und Hintergr ünde für die Reorganisation des DGB', in T. Leif, A. Klein, and H.-J. Legrand (eds.), Reform des DGB: Herausforderungen, Ausbruchspläne und Modernisierungensknozepte. Köln: Bund Verlag, 66-88.

Selznick, P. (1957). Leadership in Administration. A Sociological Interpretation. New York: Harper \& Row.

Stecklenburg, J. (1990). The Stecklenburg Report. For a More Efficient ETUC. Brussels: European Trade Union Confederation.

Sverke, M. and Sjoberg, A. (1997). 'Ideological and Instrumental Union Commitment', in M. Sverke (ed.), The Future of Trade Unionism. Aldershot: Ashgate, 277-94.

Undy, R., Ellis, R., McCarthy, W, and Halmos, A. (1981). Change in Trade Unions. London: Hutchinson and Co.

UNISON. (1993). Rules as at Vesting Day. London: UNISON.

Voss, K. and Sherman, R. (2000). 'Breaking the Iron Law of Oligarchy: Union Revitalization in the American Labor Movement'. American Journal of Sociology, 106/2: 303-49.

Waddington, J. (2000). 'Towards a Reform Agenda? European Trade Unions in Transition'. Industrial Relations Journal, 31/4: 317-30.

---- and Hoffmann, R. (2000) (eds.). Trade Unions in Europe: Facing Challenges and Searching

for Solutions. Brussels: European Trade Union Institute.

---- and Kerr, A. (1999). 'Trying to Stem the Flow: Union Membership Turnover in the Public

Sector'. Industrial Relations Journal, 30/3: 184-96.

---- Kahmann, M., and Hoffmann, J. (2003). United We Stand: A Comparison of the Trade

Union Merger Process in Britain and Germany. London: Anglo-German Foundation. 
Weil, D. (1997). Turning the Tide: Strategic Planning for Labor Unions. Winchester, MA: Book Tech. 